\title{
Pemanfaatan Media Sosial Instagram oleh Endorser dalam Membangun Citra Diri
}

\author{
Revina Saputera, H.H. Daniel Tamburian \\ revina.saputera@gmail.com,danielt@fikom.untar.ac.id \\ Fakultas Ilmu Komunikasi Universitas Tarumanagara
}

\begin{abstract}
This study discusses The Utilization of Social Media Instagram by Endorser In Building Self Image. This study aims to find out how Instagram can make people famous, to know the progress of endorsers in Jakarta, and to find out how they are looking for profit through uploaded creative works. This research is a qualitative research with descriptive method. Data collection techniques used were interviews and observations with a number of sources and documentation. The technique of validating data uses a triangulation method which means combining from existing data with sources, namely Endorser and Followers. The results of this study are that Endorsers can build self-image from Instagram because Endorser has a personality and uniqueness so that it becomes a popular favorite and has high popularity. The benefits gained by Endorser are not only popularity but material benefits.
\end{abstract}

Keywords: Endorser, Selebgram, Instagram

\begin{abstract}
Abstrak
Penelitian ini membahas tentang pemanfaatan media sosial Instagram oleh endorser dalam membangun citra diri. Penelitian ini bertujuan untuk mengetahui bagaimana Instagram dapat membuat orang menjadi terkenal, untuk mengetahui perkembangan endorser di Jakarta, dan untuk mengetahui bagaimana mereka mencari keuntungan lewat karya-karya kreatif yang di upload. Penelitian ini merupakan penelitian kualitatif dengan metode deskriptif. Teknik pengumpulan data yang digunakan adalah wawancara dan observasi dengan sejumlah narasumber serta dokumentasi. Metode teknik pengabsahan data menggunakan metode triangulasi yang berarti menggabungkan dari data-data yang ada dengan narasumber yaitu Endorser dan Followers. Hasil dari penelitian ini adalah Endorser dapat membangun citra diri dari Instagram karena Endorser memiliki kepribadian dan keunikan sehingga menjadi prestasi yang digemari oleh publik dan memiliki popularitas yang tinggi. Keuntungan yang didapat oleh Endorser juga tidak hanya popularitas melainkan keuntungan materi.
\end{abstract}

Kata Kunci: Endorser, Selebgram, Instagram

\section{Pendahuluan}

Salah satu dampak pemanfaatan teknologi internet dalam aktivitas komunikasi manusia saat ini adalah munculnya berbagai macam platform media sosial, salah satunya adalah Instagram. Instagram merupakan salah satu new media yang menjadi media sosial yang gemari banyak kalangan pada jaman sekarang. Seperti yang kita ketahui, media sosial instagram merupakan salah satu media sosial yang tren di Indonesia. Berdasarkan data yang didapatkan melalui Kompas.com pada bulan Maret lalu, sebanyak 120 juta orang Indonesia menggunakan perangkat mobile, seperti smartphone atau tablet untuk mengakses media sosial, dengan penetrasi 45 persen. (https://tekno.kompas.com/read/2018/03/01/10340027/riset-ungkap-pola-pemakaianmedsos-orang-indonesia diakses pada tanggal 7 September 2018 pada pukul 16.30). 
Fenomena dari adanya Instagram yang menciptakan tren tersendiri dimana mulai muncul adanya endorser dengan berbagai konten yang menarik yang dapat dijadikan hiburan bahkan informasi oleh para pengikutnya. Influencer atau endorser merupakan salah satu bentuk dari influencer marketing, sebuah aktivitas pemasaran yang menggunakan orang atau akun di media sosial dengan jumlah pengikut dan pengaruh yang signifikan. (https://www.viva.co.id/digital/digilife/1006744-media-sosial-pilihan-influencer-apasaja di akses pada tanggal 2 Oktober 2018 pada pukul 09.22).

Pemanfaatan media sosial instagram juga membentuk citra diri seseorang dalam tingkatan kepuasannya masing-masing. Survei itu menemukan bahwa ada 64 persen partisipan meyakini Instagram merupakan platform media sosial buat narsis (https://www.cnnindonesia.com/gaya-hidup/20170406084102-277-205330/surveiinstagram-media-sosial-paling-narsis di akses pada tanggal 7 September 2018 pada pukul 16.45)

Media baru yang tengah marak menjadi tren dikarenakan new media telah sampai pada aspek kehidupan masyarakat. Berdasarkan latar belakang tersebut, peneliti akan melakukan penelitian dengan judul "Pemanfaatan Media Sosial Instagram oleh Endorser dalam Membangun Citra Diri".

Berdasarkan latar belakang dan identifikasi masalah yang telah dijabarkan diatas maka penulis merumuskan permasalahan sebagai berikut: "Bagaimana endorser membangun citra diri dengan memanfaatkan media sosial Instagram?"

Tujuan yang ingin dicapai dari adanya penelitian ini adalah: (1) Untuk mengetahui bagaimana endorser memanfaatkan Instagram dalam membangun citra diri; (2) Untuk mengetahui cara-cara endorser membangun citra diri; (3) Untuk mengetahui bagaimana followers memandang citra diri endorser.

Dalam konsep pemasaran maka dibutuhkan adanya komunikasi pemasaran. Dimana komunikasi pemasaran ini menjadi penting karena dalam pemasaran, tidak hanya fokus kepada produk yang akan dihasilkan, namun bagaimana cara kita mengkomunikasikannya dengan baik dan dapat diterima oleh konsumen. Salah satu cara adalah menggunakan cara endorsement atau brand endorser. Selebriti adalah tokoh (aktor, penghibur, atau atlet) yang dikenal masyarakat karena prestasinya di dalam bidang-bidang yang berbeda dari golongan produk yang didukung (Terence, 2003:460).

Citra diri endorser berpaku pada tingkat kebutuhan akan penghargaan (harga diri) dan juga kebutuhan aktualisasi. Menurut Muhammad Bukhari (2005), dimana saat kebutuhan sudah memiliki standar hidup yang lebih tinggi, kebutuhan terkait dengan pertumbuhan pribadi dan prestasi seperti kebutuhan penghargaan (harga diri) dan kebutuhan aktualisasi diri yang menjadi motivator perilaku (Masmuh, 2008).

Berdasarkan penjelasan tentang endorser dan citra diri diatas menyimpulkan bahwa seorang endorser/tokoh mempunyai fungsi sebagai pengiklan atau juru bicara suatu merek dengan tujuan melekatkan produk/merek pada konsumen. Dimana seorang endorser juga mempunyai motivasi mengapa mengiklankan suatu produk/ merek. Pembawaan atau sikap yang ditunjukkan menunjukkan citra diri seseorang sehingga mempunyai motivasi dalam melakukan suatu hal, dimana kebutuhan tersebut dapat mencapai pada tingkatan tertinggi yaitu aktualisasi diri. Citra diri berhubungan dengan tingkatan kebutuhan-kebutuhan dimana citra diri menunjukkan pada tingkatan kebutuhan yang telah dicapai oleh diri seseorang. 
Sikap dan pembawaan yang ditunjukkan inilah yang menjadi citra diri dari seorang endorser dimana timbul adanya dorongan atau motivasi untuk memenuhi suatu kebutuhan oleh diri endorser itu sendiri. Kebutuhan dari tingkat penghargaan dan aktualisasi diri inilah yang mendorong adanya citra diri dari kebutuhankebutuhan endorser melalui pemanfaatan media sosial instagram. Terbukti jika kebutuhan semakin terpenuhi, semangat bekerjanya pun akan semakin baik pula.

\section{Metode Penelitian}

Dalam penelitian ini, penulis menggunakan metode kualitatif deskriptif. Penulis menggunakan penelitian deskriptif karena penulis ingin membuat deskripsi dan gambaran yang secara sistematis, faktual, dan juga akurat tentang bagaimana citra diri terbangun dari penggunaan media sosial.

Strategi penelitian yang dilakukan oleh penulis dalam penelitian ini adalah studi kasus. Penelitian ini difokuskan pada suatu kasus saja dan dipahami secara mendalam. Studi kasus yang akan dibahas adalah bagaimana citra diri seorang endorser terbangun dari penggunaan media sosial instagram.

Subyek penelitian penulis adalah Emily Youngru sebagai endorser yang sudah banyak dikenal masyarakat. Maka obyek penelitian penulis adalah pemanfaatan media sosial oleh endorser. Dimana obyek yang diteliti akan membahas tentang tema pemanfaatan media sosial instagram oleh endorser dalam membangun citra diri.

Metode pengumpulan data juga dilakukan oleh penulis dengan wawancara. Wawancara yang akan diajukan oleh peneliti adalah untuk mengetahui bagaimana pemanfaatan media sosial oleh endorser. Observasi non-partisipan juga melibatkan followers dari key informan sebagai pengamat independen. Selain itu, ada studi kepustakaan dan juga penelusuran data online yang mempunyai kemiripan dengan yang diteliti penulis.

Dalam melakukan uji keabsahan data, peneliti menggunakan teknik triangulasi sebagai alat untuk menguji validasi data. Penulis akan mendapatkan data yang berbeda dari berbagai sumber, maka dari itu perlu adanya proses triangulasi dimana proses pemfilteran suatu data yang didapat berbeda menjadi suatu kesimpulan yang memiliki kesamaan. Dengan demikian, triangulasi sumber berarti membandingkan (mencek ulang) informasi yang diperoleh melalui sumber yang berbeda. Misalnya, membandingkan hasil pengamatan dengan wawancara (Gunawan, 2014: 219).

\section{Hasil Temuan dan Diskusi}

Dengan adanya media sosial yang sekarang ini semakin canggih, kita dapat melihat kehidupan para selebriti dengan Instagram ataupun media sosial lainnya. Instagram tidak asing lagi bagi kita dikalangan milenial sekarang. Selebriti dipandang sebagai individu yang digemari oleh masyarakat dengan prestasinya, kepribadiannya, serta daya tarik fisik. Endorser yang peneliti akan wawancara adalah Emily Young, dimana sosok Emily ini adalah jebolan Indonesian Idol 2008. Ia memiliki paras yang cantik sehingga sekarang menjadi seorang endorser. 
Gambar 1. Instagram Emily Young

(0) Instagram
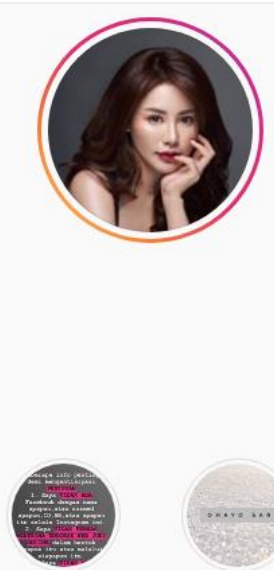

INFO PENT..

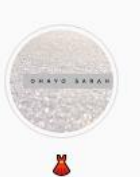

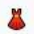

\section{emilyyoungryu *}

3,868 posts $\quad 436 \mathrm{k}$ followers

The Army of God

Line : Emilyyoungryu1 (my admin)

Ri: Ryu's mom

PJKT

G Saya Tidak Punya FACEBOOK dan sosmed lainnya.

\#singer \#entrepreneur \#armyofgod \#blogger

Followed by satuagency, leerendy, deer.case +40 more

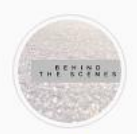

붕

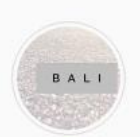

Q

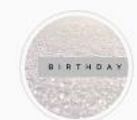

(2) (a) $0 \stackrel{\circ}{\circ}$

Sumber: Dokumentasi Peneliti (2018)

Kemampuan media sosial instagram dalam menyampaikan suatu iklan sesuai dengan target pasar. Semakin identik dan popular seseorang dalam mempromosikan suatu produk maka semakin cepat khalayak mengenal iklan yang disampaikan. Bisa melalui mengenal selebriti tersebut terdahulu, ataupun produk yang dikenakan oleh endorser. Pada era globalisasi yang semakin modern, banyak selebriti yang membangun citra diri melalui media sosial. Mereka memanfaatkan ketenarannya sebagai bisnis mereka. Kepopuleran yang mereka miliki, menjadi peluang yang besar saat membangun karakter, dimana mereka dapat mempromosikan suatu produk atau barang dari suatu toko atau brand yang ditawarkan. Kebanyakan selebriti bersifat general sehingga suatu toko atau brand mempunyai segmentasi yang luas dengan menyesuaikan selebriti yang dipilih untuk mempromosikan suatu produk kepunyaannya.

Gambar 2. Endorsement produk kecantikan oleh Emily Young
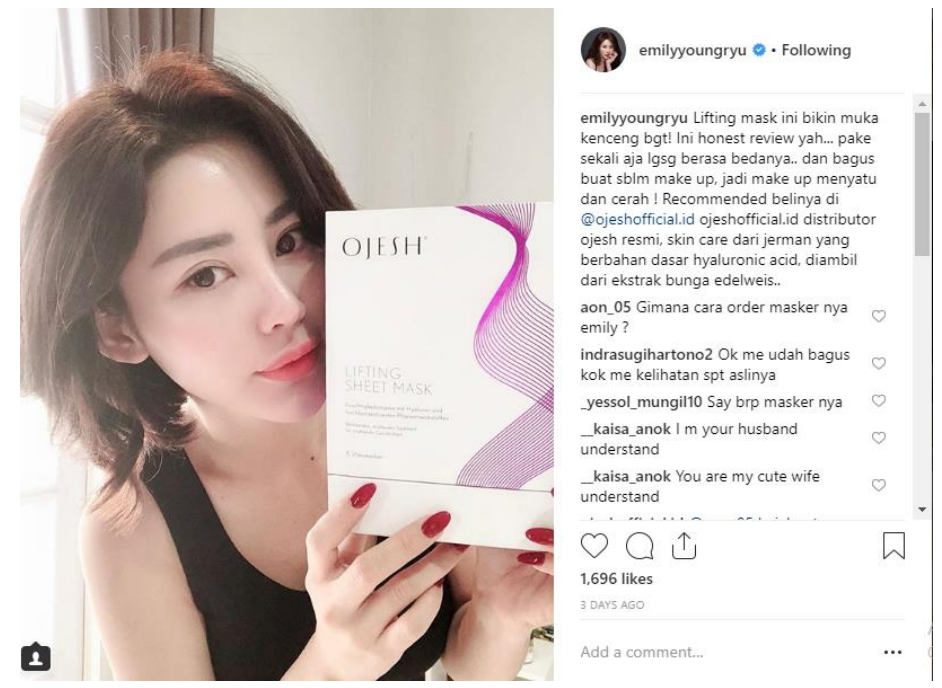

Sumber: https://www.instagram.com/p/BpyDzz7lvKr/ 
Gambar di atas menunjukkan produk kecantikan yang dipromosikan oleh sebuah toko. Menuru toko tersebut Emily Young adalah sosok yang cocok untuk mempromosikan produk tersebut karena Emily Young membangun cira dirinya dengan baik. Citra diri yang dibangun oleh Emily Young adalah beauty and fashion; dan juga seorang singer. Maka dari itu, banyak produk-produk kecantikan maupun fashion yang dipromosikan oleh Emily Young. Citra diri yang ditampilkan Emily Young dalam media sosial instagram ini juga terbilang sangat positif karena bukan sembarangan produk yang diterima oleh Emily.

Menurut Muhammad Bukhari (2005), dimana saat kebutuhan sudah memiliki standar hidup yang lebih tinggi, kebutuhan terkait dengan pertumbuhan pribadi dan prestasi seperti kebutuhan penghargaan (harga diri) dan kebutuhan aktualisasi diri yang menjadi motivator perilaku (Masmuh, 2008: 231). Kesimpulan yang dapat ditarik berdasarkan data yang diperoleh dari selebriti instagram atau endorser yaitu bahwa endorser telah mencapai pada kebutuhan hubungan sosial sehingga sudah pada tingkat kebutuhan yang standar hidupnya lebih tinggi terlihat dari pembicaraan tentang tawaran endorser dengan temannya yang memotivasi untuk mencapai tingkat kebutuhan tertinggi. Kebutuhan yang dimiliki sangat berpengaruh terhadap citra dirinya dengan memanfaatkan media sosial Instagram. Disimpulkan dengan memanfaatkan media sosial Instagram, endorser memberikan tindakan dengan memberikan konten-konten yang menunjukkan citra dirinya dan juga cerminan dirinya.

Citra diri, menurut endorser yang telah diwawancari, ditentukan oleh sikap dan pembawaan diri. Tidak hanya itu saja citra diri juga harus memperhatian ekspresi, cara berpakaian, dan juga cara berbicara di media sosial. Tidak hanya popularitas yang didapat melainkan citra diri yang dilihat oleh publik dan menjadi pencapaian yang dihasilkan oleh endorser.

Kemudian dari hasil wawancara mengenai media sosial Instagram yang dapat membangun citra diri seseorang. Menurut selebriti instagram atau endorser bahwa media sosial Instagram merupakan tempat dimana kita bisa mengeksplor, bisa berbisnis melalui media sosial dan mudah diakses oleh berbagai orang yang dapat membuat seseorang menjadi penasaran. Bahkan, bisa menjadi tempat promosi untuk bisnis kedepannya yang dibuka oleh endorser tersebut.

Tetapi tidak hanya itu, setiap pribadi masing-masing orang harus menciptakan citra dirinya masing-masing jika ingin mendapatkan hasil yang positif melalui media sosial. Seperti data yang didapat dan disimpulkan, bahwa pemanfaatan media sosial juga dapat membangun citra diri seseorang melalui ekspresi, sikap, dan juga pembawaan diri yang menjadikan cerminan diri seseorang untuk menjadi inspirasi bagi banyak orang.

Kebutuhan akan penghargaan, percaya diri dan harga diri maupun kebutuhan akan pengakuan orang lain. Dan kebutuhan aktualisasi diri, kebutuhan tersebut ditempatkan paling atas pada hierarki Maslow dan berkaitan dengan keinginan pemenuhan diri (Uno, 2016:40). Dapat disimpulkan bahwa citra diri dari Emily telah berhasil menarik perhatian dari followers dengan konten-konten yang diberikan oleh Emily dan menjadi sebuah penghargaan dari followersnya. Adanya pengakuan dan juga penghargaan yang positif dari followers menunjukkan citra diri yang berhasil diciptakan oleh Emily Young dalam memanfaatkan media sosial Instagramnya. Seperti yang dapat disimpulkan, kelebihan dari Emily dari endorser lain juga sangat detail dalam mengemas konten di Instagram dengan menunjukkan jati dirinya 
sehingga followers dapat menyimpulkan citra diri yang positif dari citra diri Emily Young. Pujian yang diberikan dari followers menunjukkan bahwa citra diri yang dibangun Emily terbukti positif di mata masyarakat.

\section{Simpulan}

Endorser merupakan cara yang efektif untuk melakukan promosi produk dan juga bisa memperluas sebuah wawasan dimana seorang endorser bisa mengetahui produk itu sebelum diberitahukan kepada followers. Dengan adanya endorser maka konsumen dapat melihat contoh produk saat dipakai oleh endorser tersebut. Endorser juga tidak hanya digunakan sebagai alat promosi yang cocok untuk online shop di Instagram tetapi juga dapat menjadi suatu alat untuk membangun citra merek online shop tersebut bahkan citra diri endorser itu sendiri.sehingga dapat meningkatkan pembelian konsumen. Penelitian ini merupakan langkah awal untuk melihat apakah media sosial Instagram dapat dimanfaatkan untuk membangun citra diri seseorang.

Dari hasil penelitian yang dilakukan dengan wawancara dapat ditarik beberapa kesimpulan. Hasil analisis wawancara yang dilakukan bahwa pemanfaatan media sosial oleh endorser membangun citra diri yang dari negatif kian menjadi positif itu penting karena dari setiap produk yang ditawarkan dan mendapat respon yang negatif juga dapat memicu untuk citra diri yang negatif begitu juga sebaliknya. Dengan respon yang positif pun membangun citra diri seseorang khususnya endorser dalam mempromosikan suatu produk.

\section{Ucapan Terima Kasih}

Penulis ingin mengucapkan terima kasih kepada:

- Ibu Dr. Riris Loisa, M.Si., selaku Dekan Fakultas Ilmu Komunikasi Universitas Tarumangara.

- Bapak Yugih Setyanto, S.Sos., M.Si., selaku Wakil Dekan Fakultas Ilmu Komunikasi Universitas Tarumanagara.

- Ibu Sinta Paramita, S.I.P., M.A., selaku Ketua Program Studi S.1 Ilmu Komunikasi Universitas Tarumanagara.

- Bapak H.H. Daniel Tamburian, S.Sos., M.Si. selaku dosen pembimbing.

- Seluruh dosen Fakultas Ilmu Komunikasi Universitas Tarumanagara.

- Emily Young, Chrisshyaren, Felice Huang, dan Ivonne Maria yang telah bersedia menjadi narasumber

- Orang tua dan teman-teman Fikom UNTAR yang telah menjadi teman seperjuangan dari awal masuk kuliah hingga saat ini.

- Seluruh staff dan karyawan UNTAR yang telah membantu penulis dalam memenuhi hal-hal yang diperlukan untuk penelitian.

\section{Daftar Pustaka}

Atmoko, Bambang Dwi. (2012). Instagram Handbook Tips Fotografi Ponsel. Jakarta: Media Kita.

Jefkins, Frank. (2004). Public Relations. Jakarta: Erlangga.

Masmuh. Abdullah. (2008). Komunikasi Organisasi dalam Perspektif Teori dan Praktik. Malang: UMM Press.

Nasrullah, Rulli. (2015). Media Sosial: Perspektif Komunikasi, Budaya, dan Sosioteknologi. Bandung: Simbiosa Rekatama Media. 
Rakhmat, Jalaluddin. (2001). Psikologi Komunikasi. Bandung: PT Remaja Rosdakarya.

Rakhmat, Jalaluddin. (2007). Psikologi Komunikasi Edisi Revisi. Bandung: PT Remaja Rosdakarya.

Romli, Khomsahrial. (2014). Komunikasi Organisasi Lengkap. Jakarta: PT Grasindo. Shimp, Terence. (2003). Periklanan promosi. Jakarta: Erlangga.

Straubhaar, J., LaRose, R. \& Davenport R. (2000). Media Now: Communication Media In The Information Age. Belmont USA: Wadsworth/Thomson Learning.

Sugiyono. (2016). Memahami Penelitian Kualitatif. Bandung: Alfabeta.

Susanto, Eko Harry. (2016). Komunikasi Manusia. Jakarta: Penerbit Mitra Wacana Media.

West, Richard, Lynn H. Turner. (2008). Pengantar Teori Komunikasi Analisis dan Aplikasi Edisi 3. Jakarta: Salemba Humanika.

Marta, R., \& Monica William, D. (2017). Studi Terpaan Media Pemasaran Melalui Posting Instagram Terhadap Ekuitas Merek Pelanggan Sumoboo!. Jurnal Komunikasi, 8(1), 68-82. Retrieved

from https://journal.untar.ac.id/index.php/komunikasi/article/view/50/53

journal.trunojoyo.ac.id//kompetensi/article/download/3533/2603

http://repository.unpas.ac.id/id/eprint/27855

http://e-journal.uajy.ac.id/10325/1/0EA19694.pdf

http://wow.tribunnews.com/2017/07/21/marshall-mcluhan-di-google-doodle-sosok-

filsuf-yang-prediksikan-lahirnya-internet?page $=$ all

http://jurnal.unpad.ac.id/jkk/article/view/7737/5328

https://tekno.kompas.com/read/2018/03/01/10340027/riset-ungkap-pola-pemakaianmedsos-orang-indonesia

https://www.viva.co.id/digital/digilife/1006744-media-sosial-pilihan-influencer-apa$\underline{\text { saja }}$

https://www.cnnindonesia.com/gaya-hidup/20170406084102-277-205330/survei-

instagram-media-sosial-paling-narsis 